\title{
EFFECT OF SOIL CEMENT COLUMN SPACING AND AREA REPLACEMENT RATIO ON EMBANKMENT BEARING CAPACITY: A QUEENSLAND CASE STUDY
}

\author{
Mark Bolton, Jay Noonan and Erwin Oh \\ School of Engineering, Griffith University, Australia
}

\begin{abstract}
This paper investigates the effect of soil/cement column diameter and spacing on bearing capacity beneath a road embankment situated on normally consolidated estuarine deposits in the South East Queensland region. The modelling was undertaken using the Finite Element method and the results are discussed with respect to the variation in parameters as described. A site investigation was undertaken during the planning stages for construction of the embankment to establish the soil profile on the site. A range of laboratory tests were performed on the undisturbed sample obtained during the investigation. The results of the laboratory tests and several alternative established methods were utilised to establish the Plaxis input parameters as discussed in this paper. The results of the analysis reveal a direct relationship between the ultimate bearing capacity and the area replacement ratio, providing a practical tool for estimating soil cement column spacings to achieve a required bearing capacity in South East Queensland conditions.
\end{abstract}

Keywords: Embankments, Soft Soils, Soil Improvement, Bearing Capacity, Queensland

\section{INTRODUCTION}

Growing development and infrastructure in South East Queensland Australia is currently spreading into areas of coastal Holocene estuarine deposits with a subsurface profile consisting of mostly unconsolidated compressible clay soils in. This soil profile is particularly prevalent in the Brisbane and Gold Coast areas in South East Queensland

Historically, the preferred construction method employed in this area for road embankments on compressible sub-surface profiles, consisted of pore pressure release mechanisms such as stone columns or pre-fabricated vertical drains. These methods were employed to assist in the rate of increase in shear strength in the sub-surface profile through primary consolidation resulting from embankment loads or engineered pre-loading. Construction delay is a significant cost in this method of geotechnical design, due to the limited shear strength / bearing capacity of the soft soils requiring staged construction to allow the gradual increase in shear strength as pore pressure is dissipated in the consolidation process. The times involved in achieving an acceptable factor of safety for stability and bearing capacity can be considerable.

Soil/cement columns have been successfully used on deeper compressible soil profiles in many locations worldwide. Previous research has shown that deep mixing has many benefits and possibilities [1]. The improvement in strength of soil through deep mixing has been shown many times in previous research [2], [3], [4] and can be cost effective when considering the advantages in time of construction as well as general construction costs [5], [3]. Soil/cement columns have been used in serval location specific applications in this region, such as the bridge abutments on the Ballina Highway Bypass but mainly on compressible soil layers of limited thickness. This paper investigates use of soil/cement columns to improve bearing capacity in the construction of earth embankments on deep alluvial clay profiles typical in the estuarine deposits at the mouths of coastal rivers in this region.

This paper presents the results of a comparative numerical study performed on a typical south east Queensland soil profile subjected to typical embankment geometry. The study compares the performance of the embankment when constructed with soil/cement columns at differing diameters and spacings. The numerical modelling has been performed using Plaxis.

\section{SUBSURFACE PROFILE}

The sub-surface soil profile chosen for this study has been shown to be representative on that found at the mouths of the coastal rivers in this region [6]. A major sub surface investigation and laboratory testing program has been completed on the site. Several boreholes were drilled in the area of the test embankment to depths of up to 20 meters. The profile adopted from the site investigation consists of a surficial layer of soil 
and rock fill to a depth of 0.7 meters overlying a compressible clay layer which continues to a depth of 19.1 meters. The soil profile and materials properties are summarized in Table 1 below:

Table 1 Subsurface Profile Properties

\begin{tabular}{cccc}
\hline Depth $(\mathrm{m})$ & $0-$ & $3.5-$ & $5.0-$ \\
& 3.5 & 5.0 & 19.1 \\
\hline Soil Type & Estuarine & Estuarine & Estuarine \\
& Silty & Sandy & Silty \\
& Clay & Silty & Clay \\
& & Clay & \\
& 1650 & 2400 & 1260 \\
$\mathrm{E}\left(\mathrm{kN} / \mathrm{m}^{2}\right)$ & 10.02 & 11.40 & 11.00 \\
$\rho_{\mathrm{d}}\left(\mathrm{kN} / \mathrm{m}^{3}\right)$ & 10.04 & 17.00 & 17.02 \\
$\rho_{\mathrm{w}}\left(\mathrm{kN} / \mathrm{m}^{3}\right)$ & 5 & 5 & 5 \\
$\mathrm{c}\left(\mathrm{kN} / \mathrm{m}^{2}\right)$ & $27^{\circ}$ & $27^{\circ}$ & $27^{\circ}$ \\
$\theta(\mathrm{degrees})$ & 0.3 & 0.3 & 0.3 \\
$\nu$ & $8.64 \mathrm{x}$ & $8.21 \mathrm{x}$ & $3.88 \mathrm{x}$ \\
$\mathrm{k}(\mathrm{m} / \mathrm{day})$ & $10^{-5}$ & $10^{-5}$ & $10^{-5}$ \\
\hline
\end{tabular}

Below 19.1 meters, a very dense layer of sandy gravel was encountered. This layer is assumed to be non-compressible and forms a permeable boundary layer in the Plaxis model. The water table was encountered at a depth of 1.0 meters below the existing surface level.

Six (6) different parameters are required in Plaxis to simulate soil behavior. These parameters are:

- Young's Moduus (E)

- Poissons Ratio (v)

- Dilatancy Angle ( $\psi$ )

- $\quad$ Permeability $(k)$

- Dry Unit Weight $\left(\gamma_{d}\right)$

- $\quad$ Saturated unit Weight $\left(\gamma_{s}\right)$

Previous research has shown that Young's Modulus can be approximated from empirical relationships. Young's Modulus has been estimated from the following:

$$
E_{s}=K_{C} C_{u}
$$

where

$$
\begin{aligned}
& E_{s}=\text { Youngs Modulus }\left(\mathrm{kN} / \mathrm{m}^{2}\right) \\
& K_{c}=\text { Correlation Factor } \\
& C_{u}=\text { Undrained Shear Strength }
\end{aligned}
$$

The correlation factor $K_{c}$ is determined from the Overconsolidation Ratio (OCR) and the soil Pasticity Index $(P I)$. The primary benefit of employing this technique is to avoid the inherent disturbance found in the undisturbed sampling procedure; particularly in sift estuarine soils that this study deals with. $K_{c}$ was estimated from the chart presented by the U.S. Army Corps of Engineers [7].

The Young's Moduli estimated for this study are presented in Table 2 below:

Table 2 Young’s Modulus Determination

\begin{tabular}{lccc}
\hline $\begin{array}{c}\text { Layer } \\
\text { Thickness }\end{array}$ & $3.5 \mathrm{~m}$. & $1.5 \mathrm{~m}$. & $14.1 \mathrm{~m}$. \\
\hline OCR & 1.9 & 1.6 & 1.3 \\
$P I$ & 28 & 29 & 31 \\
$K_{c}$ & 61 & 60 & 60 \\
$C_{u}\left(\mathrm{kN} / \mathrm{m}^{2}\right)$ & 27 & 40 & 21 \\
$E_{s}\left(\mathrm{kN} / \mathrm{m}^{2}\right)$ & 1650 & 2400 & 1260 \\
\hline
\end{tabular}

Permeability was determined from Terzaghi's theory of consolidation from the equation:

$$
k=C_{v} M_{v} \gamma_{w}
$$

where: $\quad \gamma_{w}$ is the density of water

Oedometer tests were performed on representative samples obtained during the investigation. Several oedometer tests were undertaken on undisturbed samples from varying depths and the results were collated and compared. After collation,, representative values of the coefficient of consolidation $\left(c_{v}\right)$ and the coefficient of compressibility $\left(m_{v}\right)$ were established and the values were employed for use in this case study. Table 3 presents the results representing the material at the layer midpoints.

Permeability was calculated by determining the effective overburden stress at the centre of each layer and interpolating the oedometer results. The calculated permeability values are also presented in Table 3 below:

Table 3 Consolidation Parameters and Permeability Values

\begin{tabular}{ccccc}
\hline $\begin{array}{c}\text { Layer } \\
\text { Centre } \\
(\mathrm{m})\end{array}$ & $\begin{array}{c}\sigma^{\prime} \\
\left(\mathrm{kN} / \mathrm{m}^{2}\right)\end{array}$ & $\begin{array}{c}m_{v} \\
\left(\mathrm{~m}^{2} /\right.\end{array}$ & $\begin{array}{c}c_{v} \\
\left(\mathrm{~m}^{2} /\right.\end{array}$ & $\begin{array}{c}k \\
(\mathrm{~m} / \mathrm{day})\end{array}$ \\
\hline 3.75 & 50.95 & 0.85 & 5.01 & $\begin{array}{c}8.64 \mathrm{x} \\
10^{-5}\end{array}$ \\
6.25 & 67.9 & 0.88 & 3.48 & $\begin{array}{c}8.21 \mathrm{x} \\
10^{-5}\end{array}$ \\
14.05 & 125.47 & 0.975 & 1.63 & $\begin{array}{c}3.88 \mathrm{x} \\
10^{-5}\end{array}$ \\
\hline
\end{tabular}

The Dilatancy Angle $(\psi)$ has been assumed to equal zero for all layers in the subsurface profile in accordance with Abusharar et al. [8], given the 
unconsolidated nature of the estuarine clays. Poisson's ratio for the compressible estuarine clays has been assumed to equal 0.3 [8].

The input parameters for the Plaxis analysis are summarised and presented below in Table 4 .

Table 4 Plaxis Input Soil Parameters (Insitu Profile)

\begin{tabular}{cccc}
\hline & $\begin{array}{c}3.5 \mathrm{~m} \\
\text { layer }\end{array}$ & $\begin{array}{c}1.5 \mathrm{~m} \\
\text { layer }\end{array}$ & $\begin{array}{c}14.1 \mathrm{~m} \\
\text { layer }\end{array}$ \\
\hline$c^{\prime}\left(\mathrm{kN} / \mathrm{m}^{2}\right)$ & 5 & 5 & 5 \\
$\Phi$ & 23 & 23 & 23 \\
$($ degrees $)$ & & & \\
\hline$E_{s}\left(\mathrm{kN} / \mathrm{m}^{2}\right)$ & 1650 & 2400 & 1260 \\
$K(\mathrm{~m} /$ day) & $8.64 \mathrm{x}$ & $8.21 \mathrm{x}$ & $3.88 \mathrm{x}$ \\
& $10^{-5}$ & $10^{-5}$ & $10^{-5}$ \\
$\Psi$ & 0 & 0 & 0 \\
$($ degrees $)$ & & & \\
$v$ & 0.3 & 0.3 & 0.3 \\
$\gamma_{d}\left(\mathrm{kN} / \mathrm{m}^{3}\right)$ & 10.2 & 11.4 & 11.0 \\
$\gamma_{s}\left(\mathrm{kN} / \mathrm{m}^{3}\right)$ & 16.4 & 17 & 17.2 \\
\hline
\end{tabular}

The input parameters for the soil/cement columns have been adopted from the work by Han et al (2007)[9] and Yi et al (2010) [10]. Table 5 presents the parameters for both the embankment fill material and the soil / cement columns.

Table 5 Plaxis Input Soil Parameters (Embankment and Columns)

\begin{tabular}{ccc}
\hline & $\begin{array}{c}\text { Embankment } \\
\text { Fill }\end{array}$ & $\begin{array}{c}\text { Soil / } \\
\text { Cement } \\
\text { Columns }\end{array}$ \\
\hline$c^{\prime}\left(\mathrm{kN} / \mathrm{m}^{2}\right)$ & 12.5 & 150 \\
$\Phi$ & 30 & 35 \\
$($ degrees $)$ & & \\
$E_{s}\left(\mathrm{kN} / \mathrm{m}^{2}\right)$ & 7000 & 30000 \\
$K(\mathrm{~m} /$ day $)$ & 1 & $3.88 \mathrm{x}$ \\
$\Psi($ degrees $)$ & 0 & $10^{-5}$ \\
$v$ & 0.3 & 0 \\
$\gamma_{d}\left(\mathrm{kN} / \mathrm{m}^{3}\right)$ & 20 & 0.3 \\
$\gamma_{s}\left(\mathrm{kN} / \mathrm{m}^{3}\right)$ & 22 & 20 \\
\end{tabular}

\section{FINITE ELEMENT MODELLING}

15 node triangular elements were employed in modelling the insitu soil layers. Standard fixities were also employed in modelling the boundary conditions. This results in the base line of the geometry being fully fixed in both the horizontal and vertical directions to represent the dense sandy gravel layer at the base of the soil profile that is not represented in the FEM model (See Fig. 1).

Roller conditions have been employed on the left and right boundaries to allow freedom of movement in the vertical direction while restraint is present in the horizontal direction. The far right boundary was extended to approximately 5 times the width of the embankment to avoid any effect the horizontal fixity will have on settlement.

To represent the soil and soil cement column behaviour, the Mohr-Coulomb elastic perfectly plastic model was employed. A finite element mesh was then generated using the coarse setting.

To assess the bearing capacity of the soil with different ground improvement techniques the embankment has been replaced with a plate element. To make the plate element rigid, large values of $E / A$ and $E / I$ have been used. The plate element is loaded with a uniformly distributed load that is large enough to make the soil body collapse.

To assess the bearing capacity of the untreated and treated soil in PLAXIS, the calculation process has one stage for the untreated and vertical drain treated models, and two stages for the soil cement treated models. For the untreated and treated models, a calculation phase that initiates the load that will cause failure of the soil body was common. The additional stage in the soil/cement treated models was carried out to generate the initial stresses in the soil by gravity loading.

When gravity loading is adopted, the initial stresses in the soil layers at the start of the calculations are zero. The stresses are then generated by applying the soil self-weight in the first calculation phase. This was carried out using a plastic calculation in which the loading input is set to total multipliers and $\Sigma$ Mweight was set to 1.0. Once the initial stresses had been generated, the displacements were reset to zero at the start of the next calculation phase.

A uniformly distributed pressure of 1,000 $\mathrm{kN} / \mathrm{m}^{2}$ is activated. It was predetermined that this pressure would cause all FEM's to fail. When the soil body collapses, the value of $\Sigma$ Mstage will not have reached 1 . It is representative of the portion of the load that has been applied when the failure occurs.

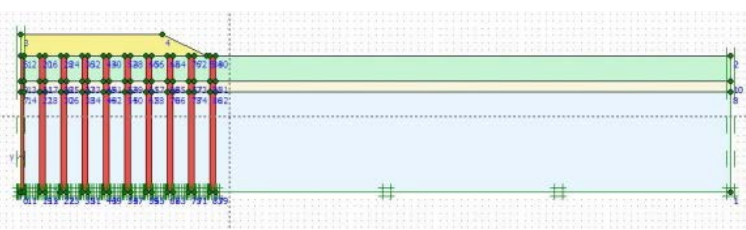

Fig. 1 Plaxis Embankment Model

\section{PARAMETRIC STUDY}

An area replacement ratio was adopted in accordance with Bergado [11]. This method has been shown previously to be acceptable in this typical profile [6]. As the column layout was square, the area replacement ratio was calculated from: 


$$
a_{S}=\frac{\pi}{4} \times\left(\frac{D}{S}\right)^{2}
$$

Where: $\mathrm{D}=$ the column diameter

$\mathrm{S}=$ the centre to centre column spacing

To determine the effect of centre to centre spacing has on settlement and bearing capacity in South East Queensland estuarine clays, models have been run with 2, 3 and 4 metre spacings with column diameters from 500 to $1000 \mathrm{~mm}$. Table 6 below presents actual area replacement ratios for each spacing and diameter.

Table 6 Area Replacement Ratios for varied Centre to Centre Spacings

\begin{tabular}{|c|c|c|c|}
\hline \multirow[b]{2}{*}{$\begin{array}{l}\text { Diam. } \\
\text { (m) }\end{array}$} & \multicolumn{3}{|c|}{ Area Replacement Ratio $\left(a_{s}\right)$} \\
\hline & $\begin{array}{l}\text { Spacing } \\
=2 \mathrm{~m}\end{array}$ & $\begin{array}{l}\text { Spacing } \\
=3 \mathrm{~m}\end{array}$ & $\begin{array}{l}\text { Spacing } \\
=4 \mathrm{~m}\end{array}$ \\
\hline 1 & 0.196 & 0.087 & 0.049 \\
\hline 0.9 & 0.159 & 0.070 & 0.040 \\
\hline 0.8 & 0.127 & 0.056 & 0.031 \\
\hline 0.7 & 0.096 & 0.043 & 0.024 \\
\hline 0.6 & 0.071 & 0.031 & 0.018 \\
\hline 0.5 & 0.049 & 0.022 & 0.012 \\
\hline
\end{tabular}

\section{RESULTS}

The ultimate bearing capacity of the untreated soil is $85 \mathrm{kN} / \mathrm{m}^{2}$, as shown in the following load / displacement curve, Fig. 2.

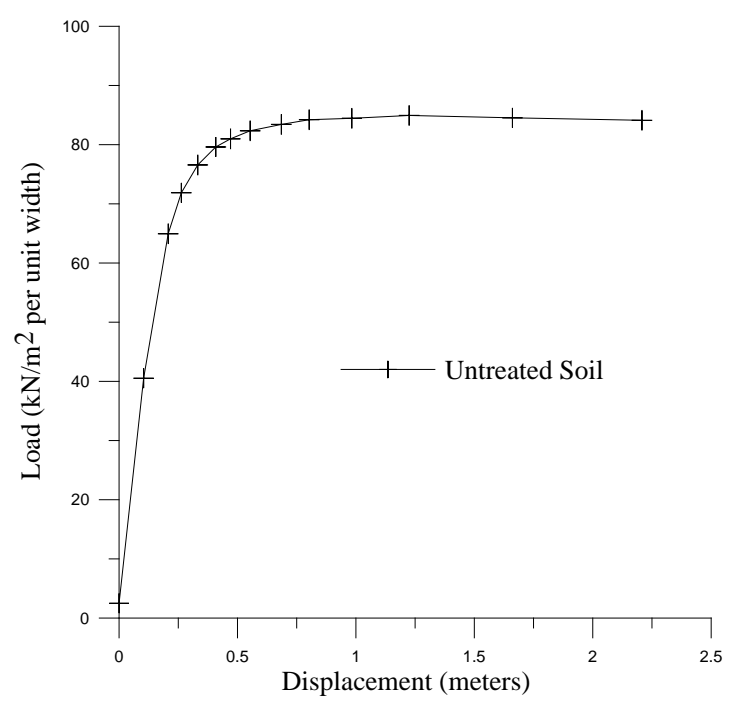

Fig. 2 Load / Displacement Curve of Untreated Soil Profile

The load displacement curves for column diameters from $500 \mathrm{~mm}$ to $1,000 \mathrm{~mm}$ at a $2 \mathrm{~m}$ centre to centre spacing's can be seen in Fig. 3. The bearing capacity for each diameter column is summarised in Table 7. Soil/cement columns with $2 \mathrm{~m}$ centre to centre spacing increase the bearing capacity of the ground significantly.

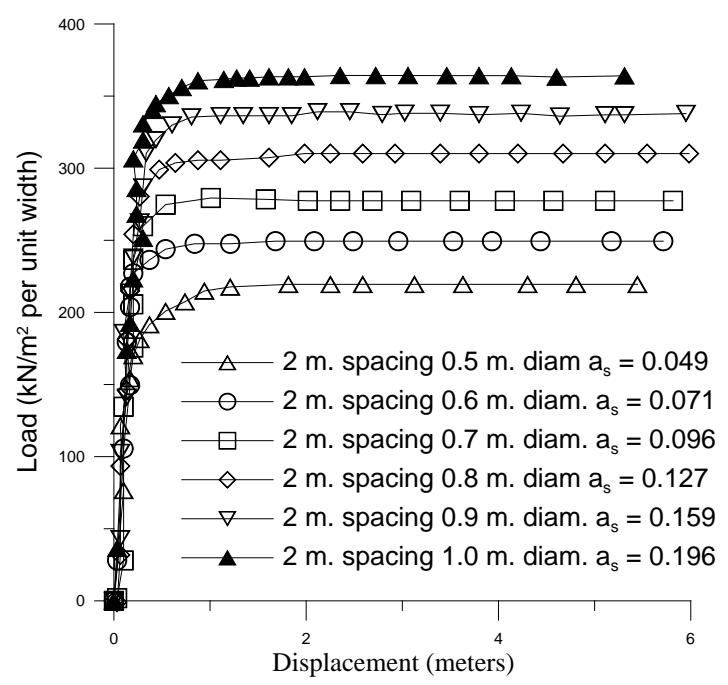

Fig. 3 Load / Displacement Curve 2 metre Column Spacings

Table 7 Bearing Capacity: 2m Centre to Centre Spacing FEM's

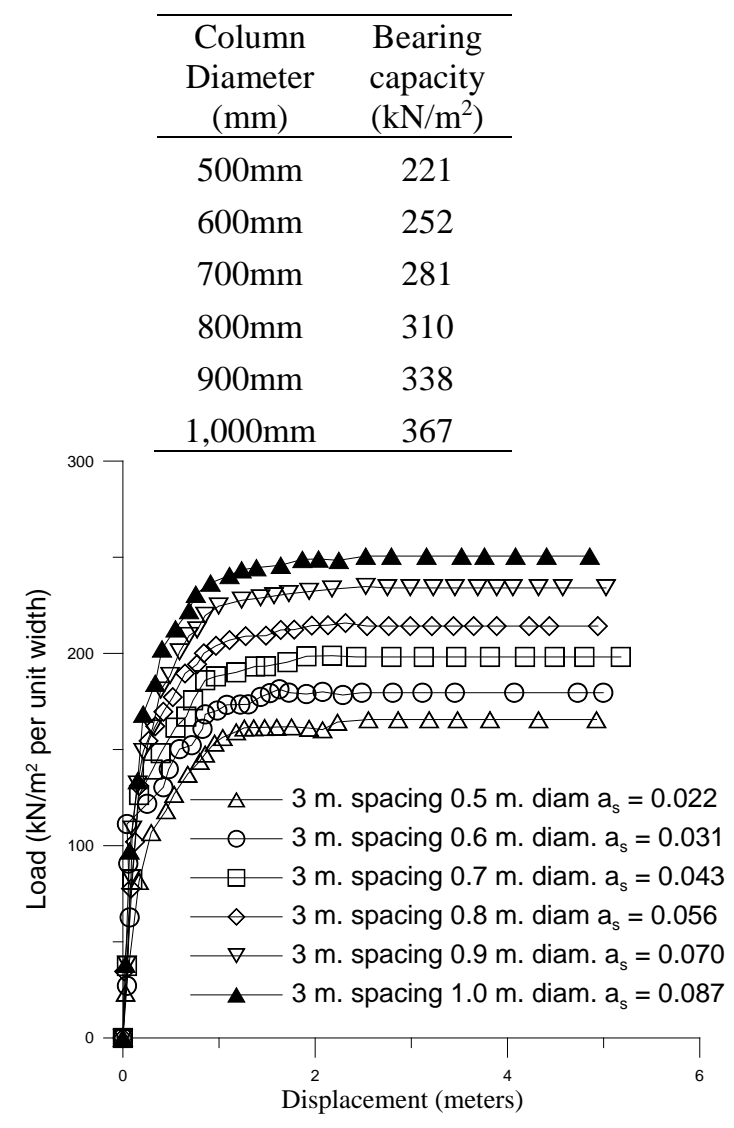

Fig. 4 Load / Displacement Curve 3 metre Column Spacings 
Table 8 Bearing Capacity: 3m Centre to Centre Spacing FEM’s

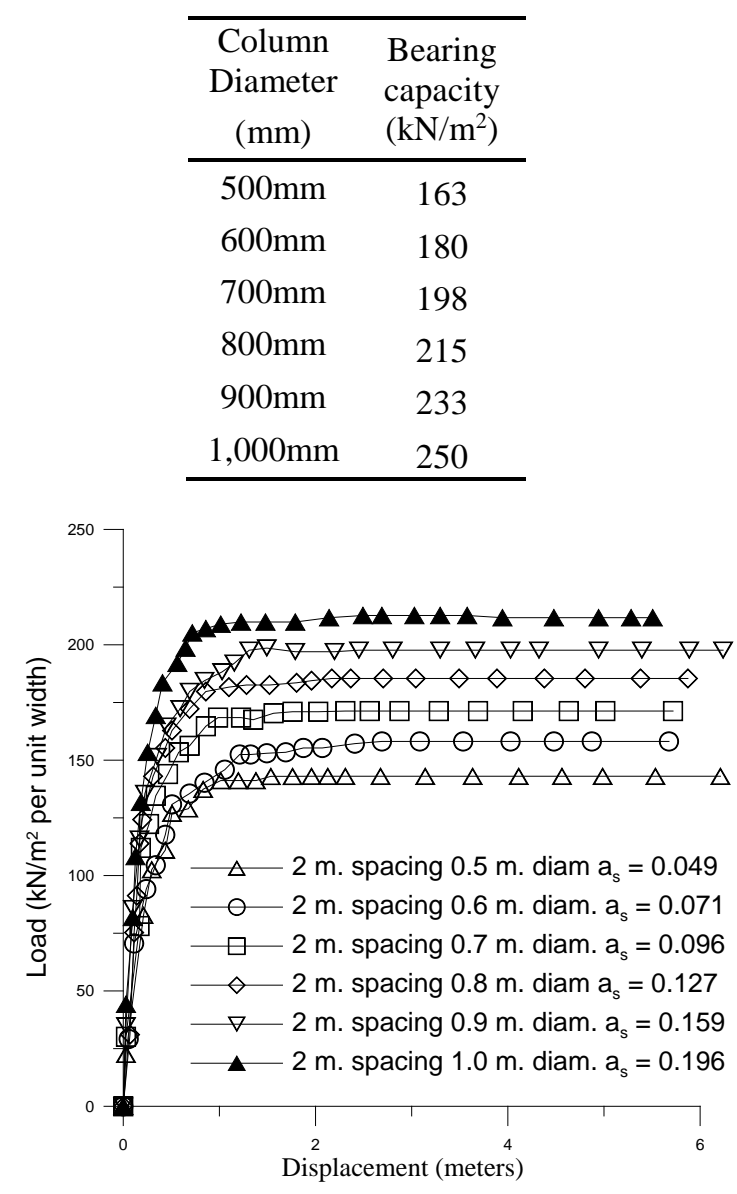

Fig. 5 Load / Displacement Curve 4 metre Column Spacings

Table 9 Bearing Capacity: 4m Centre to Centre Spacing FEM's

\begin{tabular}{cc}
\hline $\begin{array}{c}\text { Column } \\
\text { Diameter } \\
(\mathrm{mm})\end{array}$ & $\begin{array}{c}\text { Bearing } \\
\text { capacity } \\
\left(\mathrm{kN} / \mathrm{m}^{2}\right)\end{array}$ \\
\hline $500 \mathrm{~mm}$ & 147 \\
$600 \mathrm{~mm}$ & 159 \\
$700 \mathrm{~mm}$ & 173 \\
$800 \mathrm{~mm}$ & 187 \\
$900 \mathrm{~mm}$ & 200 \\
$1,000 \mathrm{~mm}$ & 214 \\
\hline
\end{tabular}

The results of the individual analyses above show the relationship between the Area Replacement Ratio and the Ultimate Bearing Capacity of the embankment on the typical soil profile. The near linear relationships show a proportional increase in bearing capacity with $\mathrm{a}_{\mathrm{s}}$. This is shown in Fig. 5.

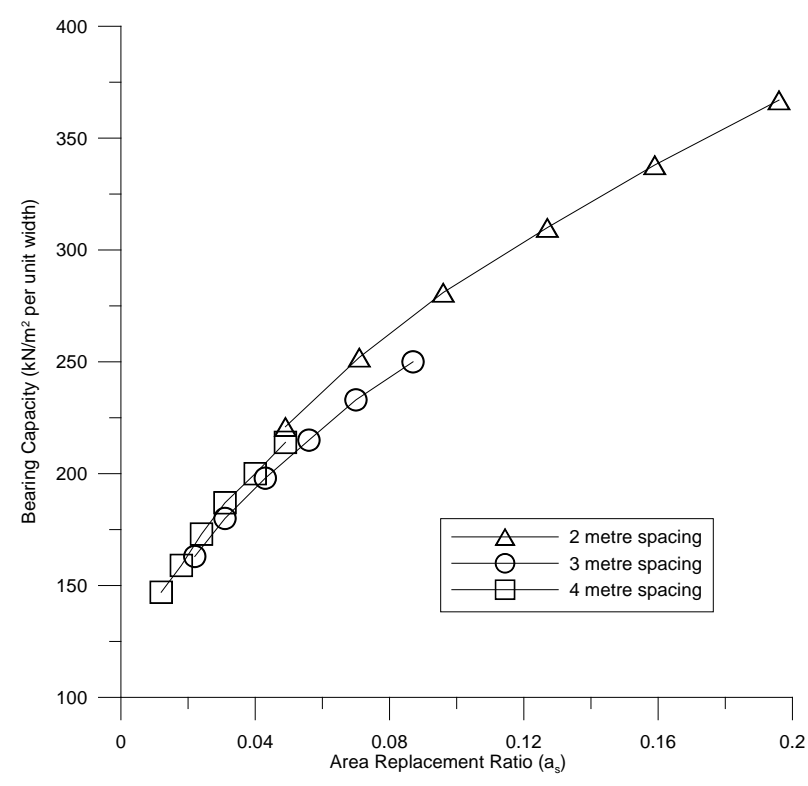

Fig. 5 Relationship Between $\mathrm{a}_{\mathrm{s}}$ and Bearing Capacity

By combining the three tested spacings, the data shown in Fig. 6 shows a near linear relationship between $a_{s}$ and ultimate bearing capacity, irrespective of column spacing.

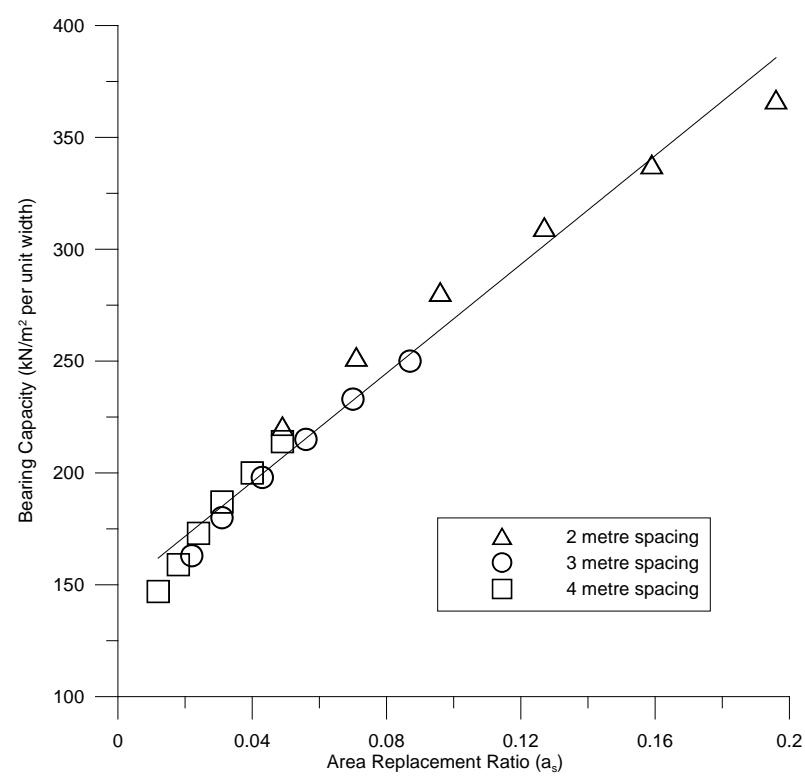

Fig. 6 Overall Linear Relationship Between $\mathrm{a}_{\mathrm{s}}$ and Bearing Capacity 
The linear relationship exhibits a correlation coefficient $\left(\mathrm{r}^{2}\right)$ of 0.97 , indication a strong relationship.

Using the above relationship, an estimation can be gained of area replacement ratio required to achieve a desired bearing capacity for a given column diameter or spacing.

Usually the diameter of the soil/cement column is known, and then the column spacing can be estimated to achieve a desired ultimate bearing capacity by establishing the required area replacement ratio from Fig. 6 above. Once $a_{s}$ is established the column spacing can be established from equation 5 below:

$$
S=\frac{D}{\sqrt{\frac{4 \mathrm{a}_{\mathrm{s}}}{\pi}}}
$$

Where: $\mathrm{D}=$ the column diameter

$\mathrm{S}=$ the centre to centre column spacing

$\mathrm{a}_{\mathrm{s}}=$ the area replacement ratio

\section{CONCLUSIONS}

The results of the Plaxis modelling show a linear relationship within each spacing group of ultimate bearing capacity with an increase in Area Replacement Ratio. Generally by evaluating the data these relationships can be shown to be statistically significant. By combining all groups of column spacing it has been shown that an overall linear relationship exists between ultimate bearing capacity and Area Replacement Ratio, as shown in Equation 4 above. This relationship shows that, given the site conditions used in this study, the ultimate bearing capacity is a direct function of the initial untreated bearing capacity and the Area Replacement Ratio.

The information provided also provides a method of estimating the required soil/cement column spacing to achieve a required ultimate bearing capacity in a typical South East Queensland estuarine soil profile.

\section{REFERENCES}

[1] Holm, G. 2000, “Deep Mixing.” Soft Ground Technology (GSP 112) Proceedings of the United Engineering Foundation, ASCE GeoInstitute Soft Ground Technology Conference, pp105-122

[2] Porbaha, A., Tanaka, H., Kobayashi, M. 1998a, "State of the art in deep mixing technology: Part II. Applications.” Ground Improvement, vol. 2 no.3, pp125-139.

[3] Holm, G. 2005, "Deep Mixing - properties and applications.” Stabilisation / Solidification Treatment and Remediation Proceedings of the International Conference on Stabilisation/Solidification Treatment and Remediation, 12-13 April 2005, Cambridge, UK (ISBN: 04-1537-460-X) pp7-10.

[4] Bruce D.A. 2001, "Practitioner's guide to the deep mixing method.” Ground Improvement, vol. 5 no. 3, pp95-100.

[5] Porbaha, A. 1998, "State-of-the-art in deep mixing technology. Part I: Basic concepts and overview of technology." Ground Improvement, vol. 2 no.2, pp81-92.

[6] Bolton, M., Noonan, J. and Oh, E., 2015, "Effect of Soil Cement Replacement Ratio on Settlement Reduction”, Electronic Journal of Geotechnical Engineering, Vol. 20, Bun. 4, pp 1457-1468

[7] U.S. Army Corps of Engineers. 1990, "Engineering and Design - Settlement Analysis.” Engineer Manual No. 1110-1-1904 30.

[8] Abusharar, S.W. Zheng, J.J Chen, B.G 2009, "Finite element modelling of the consolidation behavior of multi-column supported road embankment." Computers and Geotechnics, vol 36, no. 4, pp676-685.

[9] Han, J. Oztoprak, S. Parsons, R.L. Huang, J. "Numerical analysis of foundation columns to support widening of embankments." Computers and Geotechnics, vol 34, no. 6, November 2007, pp435-448.

[10] Yi, Y. Liu, S. Du, Y. Jing, F. Gong, N. 2010, "Comparison of Performance between Cross Shaped and Conventional Deep Mixed Columns for Three-Layered Soft Ground Improvement under Embankment Load." Ground Improvement and Geosynthetics (GSP 207) Proceedings of the GeoShanghai International Conference, ASCE, pp65-70.

[11] Bergado, D. T., Anderson, L. R., Miura, N. and Balasubramaniam, A. S. 1996, Soft Ground Improvement in Lowland and other Environments, ASCE Press, ASCE, New York, USA.

International Journal of GEOMATE, Oct., 2016, Vol. 11, Issue 26, pp. 2589-2594.

MS No. 11148 received on Nov. 11, 2015 and reviewed under GEOMATE publication policies. Copyright (C) 2016, Int. J. of GEOMATE. All rights reserved, including the making of copies unless permission is obtained from the copyright proprietors. Pertinent discussion including authors' closure, if any, will be published in Oct. 2017 if the discussion is received by April 2017.

Corresponding Author: Mark Bolton 